\title{
Does Conservatism Matter? \\ A Time Series Approach to Central Banking*
}

\author{
Helge Berger \\ CES, University of Munich \\ Ulrich Woitek \\ University of Glasgow
}

Revised Version, May 1999

\begin{abstract}
The empirical literature on central banking has found measures of central bank independence/conservatism to be negatively correlated with inflation and inflation variance across countries. But the cross-country approach has been criticised for its focus on policy outcomes instead of policies, and for the unsystematic conflation of the concepts of independence and conservatism. We present results from a single-country time series model for the German Bundesbank that avoids these shortfalls. We find that an increase in central bank conservatism leads to higher short-term interest rates and a more activist stabilisation policy with respect to macroeconomic shocks. More conservative Bundesbank regimes are associated with a less volatile economy, higher output and somewhat lower inflation. We also investigate the interaction between the central bank and the government. It turns out that nonconservative Bundesbank Councils react more strongly to macroeconomic shocks under conservative than under non-conservative government regimes.
\end{abstract}

Keywords: Central Bank Independence and Conservatism, Monetary Policy, Central Bank Government Relations, Generalised Impulse Responses.

JEL: E32, E58, E63, C32

Helge Berger

Center for Economic Studies

University of Munich

Schackstrasse 4

80539 Munich

Germany

h.berger@ces.vwl.uni-muenchen.de
Corresponding author:

Ulrich Woitek

University of Glasgow

Dept. of Economics

Adam Smith Building

Glasgow G12 8RT

United Kingdom

U.Woitek@socsci.gla.ac.uk

\footnotetext{
We would like to thank John Ashworth, Jim Malley, Anton Muscatelli, Sheilagh Ogilvie, Michael Reutter, and Lars Svensson for helpful comments and suggestions. The paper profited from comments at seminars in Glasgow, Groningen, Munich, Stockholm (IIES), and the 1999 Royal Economic Society and European Public Choice conferences in Nottingham and Lisbon. Berger acknowledges the support and hospitality of IIES, University of Stockholm, where parts of the revision were carried out.
} 


\section{Introduction}

Rogoff 's (1985) "conservative central banker" is widely considered to be a possible remedy for the time-inconsistency problem in monetary policy described by Kydland and Prescott (1977). In equilibrium, so the argument goes, rational wage setters will realise that the more conservative and independent a central bank is relative to the government, the fewer incentives it has to exploit short-term rigidities in the labour market by following an expansionary policy. Thus, given a sufficient degree of independence and everything else being equal, central bank conservatism and equilibrium inflation should be negatively correlated. The characteristics of a conservative central bank with regard to stabilisation of macroeconomic shocks depend to some degree on the structural and dynamic characteristics of the economy. The Svensson (1998) model, for instance, predicts that a more conservative central banker will react more strongly not only to shocks in inflation, but also to output shocks (cf. Ball, 1998). The reason is that monetary policy instruments work through intermediate variables such as output. Shocks to these variables might prove to be as strong a threat to price stability as shocks to inflation. A similar argument holds for exogenous money shocks. If a conservative central bank is indeed following a more active stabilisation policy, the more conservative the monetary regime, the less volatile the economy should be.

The empirical literature to date focuses almost exclusively on policy outcomes. As Cukierman (1996) and Eijffinger and de Haan (1996) report, there is hardly a paper that does not find a significant negative correlation between central bank independence/conservatism on the one hand and inflation and inflation variance on the other. Recently, however, such findings have received a fair amount of criticism. Obviously, focusing on differences in policy outcomes such as inflation instead of on differences in policies might produce misleading results if other determinants of outcomes remain unexamined. Many cross-country studies omit control variables altogether. ${ }^{1}$ A second evident problem is that most papers use indices of central bank characteristics that mix measures of conservatism and independence. While the assumption that a higher degree of independence from the government implies a higher degree of conservatism appears to be reasonable in some circumstances, a more careful approach should focus on the two aspects separately. ${ }^{2}$ Yet another criticism concentrates on measurement. Many indices of

\footnotetext{
${ }^{1}$ For instance, Romer (1993) argues that openness is an important determinant of cross-country differences in inflation. An exception from the outcome-oriented literature is, for example, Eijffinger et al. (1996), which uses a panel data approach to compare monetary policy across countries using simple reaction functions for short-term interest rate changes.

${ }^{2}$ The only paper in the cross-country tradition that follows this approach is de Haan and Kooi (1997). They
} 
central bank characteristics are based on a comparison of institutional and legal arrangements an approach that Forder (1996) has criticised because theory points to differences in behaviour and not to differences in rules. ${ }^{3}$ A related issue is the possible endogeneity of central bank status. Posen $(1993,1995)$ argues that the strength of the financial sector rather than the legal status of the central bank determines the degree of conservatism and independence of a central bank. While this particular result may have its shortcomings (Eijffinger and de Haan 1996), Posen's general observation should be taken seriously.

In the light of the prevailing interest in central bank reform, the criticisms of the existing literature on central bank independence/conservatism are important. If the success of Rogoff's (1985) "conservative central banker" were essentially the artefact of a neglect of policy analysis and of methodological flaws, recent institutional reforms towards more central bank independence and conservatism, including the installation of a highly autonomous European System of Central Banks, might be ill fated. ${ }^{4}$ But it is by far too early to close the case against the Rogoff solution. In fact, in what follows we will provide proof that many of the criticisms justly levelled at the traditional cross-country approach can be avoided by turning to a single-country time-series analysis. Selecting the example of Germany's Bundesbank, one of the world's most independent central banks, we find evidence that "conservatism matters" with regard to both policy and policy outcomes.

Consider for a moment the advantages of the single-country approach. A major benefit is that it is easier to draw a distinction between central bank independence and conservatism. It is generally believed that the German Bundesbank has enjoyed a relatively high legal and, for that matter, actual independence since the early 1950s (Berger 1997a, Maier and de Haan 1998). In addition, according to Cukierman (1992), the bank's legal degree of independence has remained unchanged throughout the entire post-war period. At the same time, the information available on the changing membership of the Bundesbank Council, the German central bank's equivalent of the Monetary Policy Committee of the Bank of England, allows inferences to be made about the time path of the Bundesbank's degree of conservatism over

construct separate cross-country indices for conservatism and independence. They find only weak evidence for an impact of conservatism on inflation or inflation variability. Of the various measures of independence, only instrument independence shows the expected influence on inflation.

3 Exceptions include Cukierman's (1992) turnover index. See de Haan (1995) for an evaluation of this approach.

4 See Walsh (1995) for the alternative contract-based solution to time-inconsistency in monetary policy. For an assessment of real-world institutions falling into that category, e.g. the Federal Reserve Bank of New Zealand, see the contributions in Bernanke et al. (1999). 
the years (Vaubel 1997a). Another advantage of a single-country approach is obviously that there is no need for cross-country comparisons of different degrees of legal and actual central bank autonomy. Also, many variables considered to be possible exogenous determinants of central bank independence are more or less time-invariant. For instance, Posen's (1995) indicator of the political strength of the German financial sector is constant from the 1950s to the present. Other variables, such as the prevailing exchange rate system or the government's view on inflation, are also more easily controlled for within a single-county approach. All in all, a single country such as Germany looks like a good testing ground for the role of the "conservative central banker".

Does conservatism matter in the German case? A crucial element of our analysis is the identification of Bundesbank preferences. Rather than relying on revealed-preferences methods that attempt to disentangle economic structure and preferences (Favero and Rovelli 1999, Ceccetti et al. 1999), we base our approach on exogenous information, namely the political background of Bundesbank Council members. Our identifying assumptions are, first, that Council members bear the partisan preferences of the nominating Länder or federal government and, second, that those appointed by right-wing-dominated governments are more inflation-averse than those appointed by left-wing governments (Vaubel 1997a, Hibbs 1977). We provide evidence from individual voting behaviour in the Council in the 1950s and 1960s that supports our identifying assumptions. ${ }^{5}$ Unfortunately, the 30-year waiting period for access to Bundesbank minutes forces us to base our general analysis on the behaviour of computed Council majorities rather than on individual voting behaviour.

What we find is that conservative majorities in the Bundesbank Council are associated with somewhat higher short-term interest rates and marginally lower rates of inflation than non-conservative majorities between 1951 and 1994. In addition, conservative Bundesbank regimes are characterised by a less volatile economy: the standard deviation of output growth, money growth and inflation is lower under conservative than under non-conservative Councils. This is broadly in line with the results emerging from outcome-oriented cross-country studies.

A major benefit of the single-country approach is that it facilitates detailed analysis of central bank stabilisation behaviour. To see whether the differences in economic volatility under conservative compared to non-conservative Bundesbank regimes is due to differences in policy, we employ generalised impulse response functions drawn from standard structural VAR

\footnotetext{
${ }^{5}$ See, among others, Havrilesky and Gidea (1991) for similar evidence for the U.S. FED.
} 
models. Impulse response functions permit a glimpse of not only the direction and strength but also the dynamics of monetary policy - a feature that standard reaction function approaches lack. ${ }^{6}$ In particular, generalised impulse responses take into account the interactions between monetary policy and the economy as well as those between the policy targets of the central bank, without forcing the researcher to impose any short or long run restrictions on the parameters of the VAR model. ${ }^{7}$ Applying this method to conservative and non-conservative majorities in the Bundesbank Council, we find that conservative Bundesbank regimes were indeed associated with a more activist stabilisation policy with regard to macroeconomic shocks. The difference across regimes is stronger the larger the conservative majority in the Bundesbank Council and more pronounced for shocks to output and money then for shocks to inflation. This is in line with the theoretical predictions briefly discussed above. The results turn out to be robust with regard to changes in the exchange rate regime and cannot be explained simply by a "post-Keynesian" structural break in central bank behaviour.

To complete the analysis, we also investigate the interaction between monetary policy and the government. Recently, a number of authors have argued that monetary policy is essentially the outcome of a bargaining process between the government and the central bank (Eijffinger and Hoebrichts 1998, Franzese 1998). Accordingly, monetary policy is expected to be more conservative the more conservative are the central bank and the government. The hypothesis might, among other things, help explain the lacklustre stabilisation behaviour of leftwing majorities discussed above. And indeed, while changing government majorities have a similar influence on interest rates and inflation under both types of Bundesbank regime, we find that non-conservative Council majorities condition their stabilisation efforts on the type of government. A non-conservative Bundesbank will counter an expansionary macroeconomic shock much more aggressively if the government is conservative than if it is non-conservative. Behind this might lie the passive role of the inflation-averse German public. While it rallies behind a proposal for a conservative monetary stabilisation policy, it is unlikely actively to enforce a conservative policy when neither the government nor the central bank advocate it.

\footnotetext{
${ }^{6}$ For recent work on the Bundesbank using standard reaction function techniques see, among others, Bernanke and Mihov (1997), Clarida and Gertler (1997), and Berger and Woitek (1999).

7 Standard ways of imposing such restrictions are the Cholesky decomposition (Sims 1980), which assumes a recursive contemporaneous causal structure between the variables in the VAR, or the Blanchard-Quah decomposition (Blanchard and Quah 1989), where assumptions about the long-run relationship between the variables solve the identification problem.
} 
The remainder of the paper is organised as follows. Section 2 discusses the empirical method used and the data involved. Section 3 presents and discusses our basic results concerning the behavioural differences between more or less "conservative central bankers" in the case of the German Bundesbank. In Section 4, we investigate whether "more conservatism" also leads to a more conservative policy. Section 5 extends our analysis to include central bank/government relations. Section 6 concludes.

\section{The Empirical Method}

\subsection{Generalised Impulse Response Functions}

To capture the interaction between monetary policy and the economy, we employ a standard VAR model of the form

$$
\mathbf{Y}_{t}=\mathbf{c}+\mathbf{A}(L) \mathbf{Y}_{t-1}+\mathbf{b} r_{t}+\mathbf{u}_{t}
$$

where $\mathbf{Y}_{t}=\left(\begin{array}{llll}i_{t} & m_{t} & y_{t} & \pi_{t}\end{array}\right)^{\prime}$ is a $(4 \times 1)$ vector of observations at time $t$. The short-term (day-today) interest rate is represented by $i, m$ is the growth rate of $\mathrm{M} 1, \pi$ the CPI inflation rate, and $y$ the growth rate of production. In addition, we include the inflation of commodity prices $r$ as an exogenous variable. ${ }^{8}$ All growth rates are based on monthly data ${ }^{9}$ and computed as annual first differences. ${ }^{10}$ The $(4 \times 1)$ vector of disturbances $\mathbf{u}_{t}$ follows the usual assumptions, i.e. $\mathrm{E}\left(\mathbf{u}_{t}\right)=\mathbf{0}, \quad \mathrm{E}\left(\mathbf{u}_{t} \mathbf{u}_{t}^{\prime}\right)=\Sigma, \quad \mathrm{E}\left(\mathbf{u}_{t} \mathbf{u}_{t^{\prime}}^{\prime}\right)=\mathbf{0} \forall t \neq t^{\prime} . \quad \mathbf{A}(L)$ is a matrix polynomial in the lag operator $L$ (maximum lag length: 12$)$, and $\mathbf{c}$ is a $(4 \times 1)$ vector of constants.

Based on the VAR model described in equation (1), we compute generalised impulse responses (Koop, Pesaran, and Potter 1996, Pesaran and Shin 1998), GI, of the form:

${ }^{8}$ Estimates also include two time dummies $D_{1}=1$ 1950:01-1952:05, 0 otherwise; $D_{2}=1$ 1990:01-1994:12, 0 otherwise. The latter models the impact of German unification, the former covers the so-called EPU crisis, an early balance-of-payments crisis due to depleted raw material stocks after the War. The lifting of import restrictions towards the EPU area in May 1952 (cf. Berger 1997a) marks the end of the balance-of-payments crisis. Our main results do not depend on the introduction of these time dummies.

9 All data is available from the Bundesbank CD-Rom: "Deutsche Bundesbank: 50 Jahre Deutsche Mark. Monetäre Statistiken 1948-1997”, Munich, C.H. Beck/Vahlen.

${ }^{10}$ The original data are not seasonally adjusted; Berger and Woitek (1997a) argue that the use of annual growth rates is indeed the proper way to get rid of the seasonal component in our data. Being aware of the fact that a difference specification may lead to inconsistent results in the presence of cointegration, we also estimated the model in log levels. Since the results are robust, we decided to present the models in growth rates, because it allows easier interpretation. The one-time increase in the money stock due to German unification, a statistical artefact already well known to the Bundesbank at the time it occurred, has been subtracted before computing $m$. 


$$
\mathbf{G I}\left(h, \mathbf{d}, \boldsymbol{\Omega}_{t-1}\right)=\mathrm{E}\left(\mathbf{Y}_{t+h} \mid \mathbf{u}_{t}=\mathbf{d}, \boldsymbol{\Omega}_{t-1}\right)-\mathrm{E}\left(\mathbf{Y}_{t+h} \mid \boldsymbol{\Omega}_{t-1}\right)
$$

These impulse responses can be interpreted as the difference between two $h$-step forecasts of $\mathbf{Y}$, based on the set on information available at time $t, \Omega_{t-1}$. We predict $\mathbf{Y}$, given that our system is hit by a vector of shocks $\mathbf{d}$ at time $t$, and subtract from this forecast the forecast of $\mathbf{Y}$ without the shocks. Generalised impulse responses allow us to analyse this question by taking into account the contemporaneous correlation between the variables, which are given by the off-diagonal elements of the error variance-covariance matrix. Reinterpreting the impulse response function according to equation (2), we avoid the usual identification problems in VAR analysis.

In what follows, we are interested in the reaction of the interest rate $i$, the Bundesbank's principal policy instrument, to shocks in the three other endogenous variables in the model. We will consider both singular one-standard-deviation shocks to either $y, m$ or $\pi$, and a simultaneous compound one-standard-deviation shock to all three variables. The vector d will be restricted accordingly. We will discuss the more general case of a compound shock first. Assume that the system is hit by a shock vector of shocks d. As generalised impulse response we obtain

$$
\begin{aligned}
G I\left(h, \mathbf{d}, \boldsymbol{\Omega}_{t-1}\right)= & \underbrace{\mathrm{E}\left(i_{t+h} \mid \mathbf{u}_{2 t}=\mathbf{d}, \boldsymbol{\Omega}_{t-1}\right)}-\underbrace{\mathrm{E}\left(i_{t+h} \mid \boldsymbol{\Omega}_{t-1}\right)}_{=0} . \\
=\mathbf{e}_{1}^{\prime}\left(\mathbf{B}_{h} \mathrm{E}\left[\mathbf{u}_{t} \mid \mathbf{u}_{2 t}=\mathbf{d}\right]\right), & .
\end{aligned}
$$

where $\mathbf{B}_{h}$ is the parameter matrix of the MA-representation of the underlying VAR model at lag $h$, and $\mathbf{e}_{1}$ is a $(4 \times 1)$ vector with 1 as the first element and zeroes as the other three elements. ${ }^{11}$ The $(3 \times 1)$ vector $\mathbf{u}_{2 t}$ contains the disturbances to $y, m$, and $\pi$.

What we need next is an expression for $\mathrm{E}\left[\mathbf{u}_{t} \mid \mathbf{u}_{2 t}=\mathbf{d}\right]$. Only the first element of the vector of conditional expectations of $\mathbf{u}_{t}$ is unknown at the moment, since the last three elements are given by $\mathbf{d}$. To derive this expression, we partition $\mathbf{u}_{t}$ in the following way, and assume that the distribution is multivariate normal:

$$
\begin{aligned}
& \mathbf{u}_{t}=\left(\begin{array}{l}
u_{1 t} \\
\mathbf{u}_{2 t}
\end{array}\right) \rightarrow N(\mathbf{0}, \Sigma) ; \\
& \Sigma=\left(\begin{array}{ll}
\sigma_{11} & \sigma_{12} \\
\sigma_{21} & \Sigma_{22}
\end{array}\right)
\end{aligned}
$$

${ }^{11}$ The vector $\mathbf{e}_{1}$ extracts the first row elements (i.e. the interest rate reaction) of the resulting vector of 
where $\sigma_{11}$ is the variance of the shock to $i, \Sigma_{22}$ is the $(3 \times 3)$ covariance matrix of the shocks to $y, m$, and $\pi$. The $(1 \times 3)$ vector $\sigma_{12}$ contains the covariances of the shocks to $y, m$, and $\pi$ and the shock to $i, \sigma_{12}=\sigma_{21}^{\prime}$. The conditional expectation of $u_{1 t}$ is now given as

$$
\begin{aligned}
\mathrm{E}\left[u_{1 t} \mid \mathbf{u}_{2 t}=\mathbf{d}\right] & =\mathrm{E}\left[u_{1 t}\right]+\boldsymbol{\sigma}_{12} \Sigma_{22}^{-1}\left(\mathbf{d}-\mathrm{E}\left[\mathbf{u}_{2 t}\right]\right)= \\
& =\sigma_{12} \Sigma_{22}^{-1} \mathbf{d} .
\end{aligned}
$$

The vector $\mathbf{d}$ can be normalised in the usual way, i.e. by looking at shocks of asize of one standard deviation. Hence, we end up with the following expression:

$$
\begin{aligned}
\mathrm{E}\left[\mathbf{u}_{t} \mid \mathbf{u}_{2 t}=\mathbf{d}\right] & =\left(\begin{array}{c}
\sigma_{12} \Sigma_{22}^{-1} \mathbf{d} \\
\mathbf{d}
\end{array}\right) ; \\
\mathbf{d} & =\left(\begin{array}{c}
\sqrt{\sigma_{22}} \\
\sqrt{\sigma_{33}} \\
\sqrt{\sigma_{44}}
\end{array}\right) .
\end{aligned}
$$

The equivalent expression in the more standard case of a singular shock to either $y, m$ or $\pi$ is simply

$$
G I\left(h, \mathrm{~d}, \Omega_{t-1}\right)=\left.\mathbf{e}_{1}^{\prime} \frac{\mathbf{B}_{h} \Sigma \mathbf{e}_{j}}{\sqrt{\sigma_{j j}}}\right|_{\mathrm{d}=\sqrt{\sigma_{i j}}},
$$

where the index $j$ marks the variable to which we restrict the shock.

We employ the framework described above to characterise possible differences in the conduct of monetary policy under alternative policy regimes. That is, we are interested in how German central bank behaviour differs under conservative and non-conservative majorities in the Bundesbank Council. The question is what constitutes a majority? Let us first consider a simple median-voter model. That is, we assume that the decision process in the Council can be described by a simple majority rule with the median voter having the final say in setting policy instruments. Setting the majority threshold, tr, to 50 percent, the model switches to the conservative regime whenever the conservative vote share, $s_{t}$, exceeds $t r$. Equation (1) then becomes

$$
Y_{t}= \begin{cases}\mathbf{c}_{1}+\mathbf{A}_{1}(L) \mathbf{Y}_{t-1}+\mathbf{u}_{1 t} & \text { if } s_{t}>t r \\ \mathbf{c}_{2}+\mathbf{A}_{2}(L) \mathbf{Y}_{t-1}+\mathbf{u}_{2 t} & \text { otherwise }\end{cases}
$$


where the order of the VAR is the same in both models. The final step is to compute the generalised impulse responses and compare the GI across both regimes. If the Council's decisions instead result from a bargaining mechanism, we would expect this comparison to yield different results for different levels tr. Section 3 will discuss our results in some detail.

\subsection{Identifying Conservatism}

A crucial element in the data set is the information about the composition of the central bank Council. Following Vaubel (1997a) and Hibbs (1977), we rely on two notions. First, we assume that the Council members share the partisan beliefs of the state (Länder) or federal governments that nominated them. Second, we take the view that governments dominated by the conservative party and, thus, their nominees, are more inflation-averse than those led by social democrats. Consequently, a Bundesbank Council member selected by a conservative government is classified as a "hawk", while social-democratic appointees are said to be "doves". Figure 1 shows the time path of the percentage of Bundesbank Council votes held by members appointed by governments dominated by conservatives and social democrats. The third group, termed "neutrals", consists of those members who were appointed by mixed governments and who therefore cannot be assigned to one the two "political" groups. ${ }^{12}$

[Figure 1 about here]

The conservatives on average held about 48 percent of the overall Council votes, nominees of social-democratic and neutral governments 43 and 9 percent respectively. But Figure 1 also shows considerable variance. After 1957, for instance, when the former Bank deutscher Länder became today's Bundesbank, a major shift towards a more conservative central bank Council occurred. The reason was that the Bundesbank law gave the executive board voting rights in the Council. This increased the number of members appointed by the then conservative federal government. Otherwise the Bundesbank very closely resembled its predecessor (Berger 1997a). ${ }^{13}$

One way to evaluate the identifying assumption for the preferences of the Bundesbank Council behind Figure 1 is to analyse available information on the individual voting behaviour

\footnotetext{
12 The data on the Council's composition are published in Vaubel (1997a).

13 Vaubel (1997a/b) argues that the Bundesbank Council members' political background does colour their behaviour towards incumbent governments around elections. Berger and Woitek (1997) and Neumann (1998)
} 
of its members. Information on voting is limited by two factors. First, German laws allow access to Bundesbank minutes only with a time lag of 30 years. Second, even where the minutes are available, it is sometimes impossible to infer the voting behaviour of individual members. Berger (1997b) reports some voting data on actual discount rate changes in the period 1948 to $1961 .{ }^{14}$ But the voting records are not always complete and some results have to be meticulously gathered from Council discussions. Even less information is available about votes on decisions not to change policy (cf. Neumann 1998). ${ }^{15}$

\section{[Table 1 about here]}

Notwithstanding these limitations, the available data allow analysis of dissent voting behaviour. Table 1 presents the results of OLS regressions of the percentages of "no" votes by Council members nominated by conservative, social democratic and "neutral" Länder and federal governments on discount rate changes in percentage points. Two results stand out. First, political background matters: especially social democratic appointees seem to be more likely to resist upward than downward changes of the discount rate, while conservatives in the Council cast their votes independently of the direction of the policy change. Neutral members lean in the direction of the social democrats, but the results are somewhat less clear. Across columns, $\Delta$ Discount Rate has a marginally significant positive effect on left-wing and (with exceptions) neutral but not on conservative dissent voting in the sample (columns (1) to (7)). Second, there is some herd behaviour: the dissenting vote was highly correlated among groups. Columns (3), (4), and (7) reveal that all groups were more inclined to vote "no" if members of other groups did so as well. In the case of neutral council members, this herd behaviour is sufficiently strong to render $\Delta$ Discount Rate insignificant in column (7).

The results in Table 1 are suggestive. Even when controlling for the correlation among the dissent voting behaviour of groups, it would seem that conservatives showed a preference for a more conservative monetary policy than non-conservatives, especially left-wing nominees. The result motivates a closer look at the matter, even though this means moving from individual voting behaviour to an analysis of Council majorities.

\footnotetext{
reject that hypothesis. See Sieg (1997) for a theoretical discussion.

${ }^{14}$ The information content of the Council minutes 1962-69 is, as a rule, too poor to extend the vote database.

15 There is also no systematic poll on the members' opinions on staff policy proposals that could be exploited in a quantitative analysis. Chappel et al. (1999) develop and analyse such a data set for the U.S. Fed under Arthur Burns in the 1970s.
} 


\section{Basic Results}

Table 2 presents summary statistics for the day-to-day interest rate and three possible target variables, output growth, money growth, and inflation, under conservative and nonconservative Bundesbank regimes. In the present section, we define a conservative regime (or majority) as one in which the median political (non-neutral) voter in the Bundesbank Council is nominated by a government dominated by the conservative party, i.e. when conservative nominees outnumber social democratic nominees in the Council. A non-conservative majority reigns otherwise. The definition limits the role of neutral members to casting the decisive vote in case of a tie between the political members of the Council. This seems to be broadly in line both with the results of the previous section and the group's diminishing voting power after the 1960s (see Figure 1). ${ }^{16}$

\section{[Table 2 about here]}

Table 2 shows the mean and the standard deviation of the time series under both types of regime. The original data are monthly and run from 1950:01 to 1994:12. This leaves us with 528 observations after computing growth rates, 288 of which fall under conservative and 240 under non-conservative Bundesbank majorities.

A first result is that conservative regimes are characterised by somewhat higher shortterm interest rates (5.47 vs. 5.41 percent) and marginally lower rates of inflation ( 2.99 vs. 3.01 percent) than non-conservative regimes. ${ }^{17}$ The small difference in interest rates obviously did not hurt the economy in other ways, as conservative Bundesbank Councils were also linked with higher output and money growth rates. These results are broadly in line with the findings in the majority of cross-country studies on central bank independence/conservatism and inflation (Section 1).

A second feature conveyed by Table 2 is that the volatility of the three possible target variables is smaller under conservative than under non-conservative regimes. These particular characteristics of the data are quite robust across different sample lengths and to exclusion of

\footnotetext{
${ }^{16}$ Alternatively, one could define a conservative regime as one in which the median of all Council members is conservative. The empirical results hardly differ.

17 The difference is more pronounced outside the "hard" Bretton Woods period from 1959 to 1972 (Obstfeld 1993), where conservative (non-conservatives) majorities are associated with an average interest rate of 6.68 (5.54) percent and an inflation of 2.92 (3.16) percent.
} 
the Bretton Woods period. But what lies behind these stylised facts? The explanation might reside in the way conservative and non-conservative Bundesbank majorities conduct monetary policy. A plausible hypothesis is that the Bundesbank reacts more decisively on macroeconomic shocks when the Council's median voter is conservative than when the median is non-conservative. This might contribute to less volatility in real and nominal variables and perhaps also to higher output growth and lower inflation under conservative Bundesbank regimes. The question is whether different Council majorities really react differently to shocks in output growth, money growth, and inflation. The answer is not in Table 2, however. The sample statistics only report the unconditional standard deviation of the interest rate, which seems to be more-or-less the same across Bundesbank regimes. But there is nothing to be learned about the stabilisation behaviour of conservative and non-conservative Bundesbank majorities. For this we will have to turn to the empirical methods described in Section 2.

We first produce and compare the generalised impulse responses of conservative and non-conservative Bundesbank regimes using monthly data on growth rates running from 1951:01 to 1994:12. Figure 2 presents our results for shocks in output growth, money growth, and inflation under conservative and non-conservative Bundesbank Council majorities, as formalised in equations (7) and (8). The threshold, $t r$, is set at 50 percent of all political votes. To avoid small sample bias, the 90 percent confidence intervals are calculated using a standard non-parametric bootstrap technique (Efron and Tibshirani 1993) with the small sample correction proposed by Kilian (1998). ${ }^{18}$

[Figure 2 about here]

The first columns shows the Bundesbank reaction to positive shocks to $y, m$, and $\pi$ under conservative Council majorities (VAR1), the second column the impulse responses under nonconservative Councils (VAR2). The last column plots the difference between the former and the latter (VAR1 - VAR2).

The pattern that emerges from Figure 2 is that conservative Council majorities do indeed follow a more activist policy. While the Bundesbank shows a positive and at least marginally significant positive reaction to shocks to $y, m$, and $\pi$ under conservative regimes,

\footnotetext{
${ }^{18}$ The procedure has two steps: first, the small-sample bias is estimated based on 1000 replications of the estimated model. Then, the confidence intervals are derived from 2000 replications of the corrected model (including a stationarity correction).
} 
its reaction under non-conservative regimes is much less pronounced. ${ }^{19}$ In the case of $m$, there is a even a significant negative response. The difference between both impulse responses is positive up to a three-year horizon in the case of output growth and money growth and up to about two years for inflation. Only in the latter case is the difference not significant. To allow a more comprehensive evaluation of this pattern, Figure 3 displays the results for a compound shock to $y, m$, and $\pi$ as defined in equations (3) to (6) and (8).

[Figure 3 about here]

The top figure shows the reaction of conservative regimes to the simultaneous positive shock. After an initial slightly negative reaction, conservative Bundesbank Councils react by strongly and significantly raising interest rates. The reaction reaches a maximum after about 12 months and fades out towards the end of our three-year horizon. As was to be expected from the previous findings, the conservative central banker's policy response turns out to be quite distinct from the reaction of the non-conservative regime (middle figure). The bottom figure shows that the difference is not only positive, but also statistically significant. At its maximum about twelve months after the shock, the interest rate difference between conservative and non-conservative majorities is about 0.7 percentage points. This is close to the sum of the individual interest rate responses to shocks in $y, m$, and $\pi$ at this point (Figure 2).

To check the robustness of the results displayed in Figures 2 and 3, we computed the generalised impulse response functions of both types of majority separately excluding the period of the "hard" Bretton Woods system of fixed exchange rates (Obstfeld 1993). That period runs from January 1959, when the deutschmark became fully convertible, to early 1972 , when the Bretton Woods System finally dissolved. We categorise the years after 1973 as a period of a floating exchange rate, since the Bundesbank de facto operated as the unconstrained - anchoring central bank of the European exchange rate mechanisms (Kenen 1995). We found that the results without the Bretton Woods period were similar to the results discussed above. ${ }^{20}$ A second robustness check was conducted by splitting our overall sample into "Keynesian" and "Post-Keynesian" subsamples, drawing the line in 1980. The general

19 We speak of (economic) significance when a computed impulse response function or difference is significantly different from zero for more than one period within the 36 months horizon.

${ }^{20}$ Results available on request. We also conducted a more elaborate test comparing the performance of conservative majorities within and outside the hard Bretton Woods period. The results showed that the impulse response of the interest rate was both quicker and stronger without the fixed exchange rate constraint. 
results did not differ significantly between the two periods. ${ }^{21}$ It is also reassuring that, as Table 3 reveals, both types of majority faced similar types of economic shock.

[Table 3 about here]

Table 3 shows that the residuals or shocks stemming from the estimation of equation (8) are similar in structure and volatility across Bundesbank majority regimes. The cross-correlation of the shocks (upper half of Table 3) varies somewhat, but the signs of the coefficients of correlation remain unchanged. In addition, the standard deviation of the shocks is more-or-less identical under both regimes (lower half of Table 3). We conclude that conservatives and nonconservatives worked in comparable economic environments and that preferences indeed seem to be key to understand the differences in monetary policy.

The observational pattern described above seems interesting enough to deserve some discussion on theoretical grounds. Why is it that conservative central bankers seem to be more active in stabilising, for instance, output shocks than are non-conservatives? A possible explanation is macroeconomic persistence and the lags involved in monetary policy (Svensson 1998, Ball 1998). ${ }^{22}$ Consider the example of a central bank with a standard quadratic loss function in the deviations of output and inflation from their long-run equilibrium levels that aims to counter a positive (demand) shock to output that threatens to drive up inflation. ${ }^{23}$ If

${ }^{21}$ The same holds for alternative break points before and after 1980:01. Results available on request.

22 The model assumes a one-period control lag for output (or the output gap) and a two-period control lag for inflation. Expectations are backward-looking and the model abstracts from open economy complications (cf. Svensson 1998: Appendix C). For empirical evidence suggesting that this approach is a valid description for the US and the Euro area, see Rudebusch and Svensson (1998) and Peersman and Smets (1998). The German economy is somewhat smaller and more open then these economies. The theoretical argument will still hold, however, as long as the exchange rate channel of monetary policy does not qualitatively alter the control lag structure.

23 As a formal illustration, consider the following simple static representation of the Svensson (1998) model. Demand/output is (1) $y=-\beta r+\varepsilon$, where $\varepsilon \sim N\left(0, \sigma_{\varepsilon}^{2}\right)$ is a demand shock, $\beta>0$ is a parameter, and $r$ is the central bank's policy instrument. Inflation/supply is (2) $\pi=\alpha y+\theta+\gamma \varepsilon$, where $\theta \sim N\left(0, \sigma_{\theta}^{2}\right)$ is a supply shock and $\alpha, \gamma>0$ are parameters. Note that the central bank can influence inflation only via output and that there is a spillover of demand shocks on inflation. The bank's loss function is (3) $L=\lambda\left(y-y^{*}\right)^{2}+\left(\pi-\pi^{*}\right)^{2}$, where $\lambda>0$ is the relative weight of the real target and the variables with the asterisks are the policy targets. The central bank's degree of conservatism can be defined as $1 / \lambda$. If we set $\pi^{*}=0$, insert (1) and (2), and minimise (3) with respect to $r$, the central bank's reaction function is (4) $r=1 / \delta\left[\lambda y^{*}+\left(\lambda+\alpha^{2}+\gamma \alpha\right) \varepsilon+\alpha \theta\right]$, where $\delta=\beta\left(\lambda+\alpha^{2}\right)$. It is straightforward to show that the coefficients of both the demand and the supply shock, $\varepsilon$ and $\theta$, are strictly decreasing in $\lambda$. It follows that the reaction to shocks in output and inflation is increasing in $1 / \lambda$, the central bank's degree of conservatism. Note that, in the absence of spillovers of output shocks onto inflation, i.e. for $\gamma=0$, the central bank's reaction to $\varepsilon$ is independent of $\lambda$. This, in a nutshell, is the argument 
changes in output and inflation are persistent, the shock will influence future inflation through two channels. First, it will increase inflation (possibly with a lag) because the shock drives up demand for a given supply. It will continue to do so in future periods, as well, because the persistence of output carries the surge in demand into the future. Second, once being tipped off its equilibrium level, inflation will also continue to rise because of persistence. If the central bank were able immediately to compensate for the initial output shock, it would do so no matter its degree of conservatism, because there is no trade-off between the price and output stability involved. Stabilising output will also ensure stable prices. But things change if the bank can influence output only with a time lag. Then it will have to distort output from its target level to compensate for both the lagged output effects of the shock and the lagged repercussions on inflation. The more conservative it is, i.e. the less weight it puts on avoiding output fluctuations, the more recklessly it will do so. In other words, we should expect more conservative central bank Councils to raise interest rates more strongly in a reaction to output shocks than a less conservative institution. This is just what we observe in Figure 2 above. A similar argument can be made concerning shocks to money. Here, a more conservative central bank should also be expected to react more strongly than a less conservative bank. Again, Figure 2 indicates that this is the case.

Turning to shocks directly affecting inflation, the same argument should, in principle, apply again: the more conservative the central bank is, the more strongly it will raise interest rates to depress demand and thus, over time, inflation. However, this is less visible in Figure 2. While there seems to be a somewhat stronger reaction by conservative Council majorities than by non-conservative Councils, the difference is relatively small compared to the reactions to output and money shocks, and is not significant. Two possible explanations come to mind. First, if the spillovers of shocks to output or money on inflation are the predominant source of inflation variance, i.e. more important than direct shocks to inflation, an increase in the degree of conservatism might also decrease the relative importance of inflation shocks. ${ }^{24}$ Second, from a more political economy point of view, it could be argued that especially non-conservative central bank Councils find it easier to take a tough stance on shocks to inflation. In contrast to output shocks, which might influence inflation only with a lag and could require politically

\footnotetext{
alluded to in the text.

${ }^{24}$ Cf. Svensson (1998: Appendix C). In the terminology of the simple model discussed in the previous footnote, this would be the case of large spillovers of output shocks on inflation, $\gamma$. A bit more formally, a higher degree of conservatism (a lower $\lambda$ ) will have a stronger impact on the central bank's reaction to output shocks than on inflation shocks if $\gamma>1$.
} 
difficult "pre-emptive" policy action before inflationary pressure becomes visible (Blinder 1998), a contractionary reaction to a sudden surge in inflation is more-or-less self-explanatory and less likely to provoke criticism from trade unions. ${ }^{25}$

\section{The Council's Decision Mechanism}

The median voter model is not the only possible mechanism on which the Bundesbank Council's decisions could be based. A plausible alternative conjecture would be that its decisions emerge from a bargaining process. This would imply that the Bundesbank's policy should get more conservative the larger the conservative voting majority.

To see whether the bank's behaviour does indeed change with the Council majority, we vary the threshold $t r$ in model (8). The number of observations available in our data set limits this exercise to the interval between 43 and 50 percent. To be able to compare the strength of the interest rate reaction differential between conservatives and non-conservatives under different thresholds, we compare the accumulated interest rate differentials in their reaction to a compound expansionary shock. In other words, we compare the integral under differential impulse responses like the one displayed in the bottom panel of Figure $3 .^{26}$

[Figure 4 about here]

If there is a link between the degree of conservatism of the Council and the reaction to shocks, we would expect a increase in the accumulated interest rate differentials, if the proportion of conservative votes increases. Figure 4 provides some tentative indications that this is actually the case. The more conservative the Bundesbank Council, the stronger the bank's policy reaction to expansionary macroeconomic shocks. In all cases the differences between regimes are significant.

The results suggest the presence of elements of a bargaining mechanism behind the Bundesbank's monetary policy decisions. The larger the conservative majority, the more austere is this majority's reaction to expansionary shocks relative to that of non-conservative majorities. However, Figure 4 does not answer the question of which threshold actually results in the best fit of the model. To address this issue, we treat model (8) as a multivariate version

\footnotetext{
25 Alternatively, it could be argued that non-conservative majorities decide to act on shocks to inflation rather than on shocks to output, in order to uphold a reputation as hard-nosed central bankers.

${ }^{26}$ Our results do not, however, depend on the specific method chosen. We get quite similar results if we, for
} 
of the threshold autoregressive model discussed by Tong (1993), and implement a grid-search by varying $t r$ and the orders of the two VARs, $p_{1}$ and $p_{2}$. For each combination, we calculate Akaike's information criterion $(A I C)^{27}$ for both models, $A I C_{1}$ and $A I C_{2}$. The selected combination of $t r, p_{1}$, and $p_{2}$ is the one that minimises the weighted sum $A I C=\left(A I C_{1}+A I C_{2}\right) / T$, where $T$ is the effective number of observations. ${ }^{28}$ The grid-search selects a threshold of just 47.36 percent of all political votes in the Bundesbank. Obviously, a threshold below the 50 percent cut-off point suggested by the median voter model is sufficient to draw a clear distinction between conservative and non-conservative Bundesbank regimes. Alternatively, it could be argued that the Council's non-conservative members are less disciplined and, thus, less homogenous in their voting behaviour than their conservative counterparts. The latter interpretation holds an element of preference-reversion ("Thomas-à-Becket effect") discussed, among others, by Neumann (1991).

\section{Central Bank and Government}

Monetary policy is not conducted in a political vacuum. Any central bank, even the Bundesbank or the U.S. Fed, is in the end accountable to the democratic sovereignty represented by the government. Authors such as Eijffinger and Hoebrichts (1998) and Franzese (1999) argue that decisions on monetary policy therefore are best represented by a bargaining framework which includes both the central bank and the government. To see the gist of this argument, assume that the effective loss function on which monetary policy decisions are based is (ignoring a possible money growth target)

$$
L_{t}=\left(\pi_{t}-\pi^{*}\right)^{2}+\lambda\left(y_{t}-y^{*}\right)^{2} \text {, }
$$

where $\pi^{*}$ and $y^{*}$ are inflation and output growth targets. $\lambda>0$ measures the relative importance of the real target, which makes $1 / \lambda$ a measure of the inflation aversion. $\lambda$ is determined as a weighted average of the form

$$
\lambda=\gamma \lambda_{C B}+(1-\gamma) \lambda_{G o v}
$$

where $0 \leq \gamma \leq 1$ is the central bank's degree of independence from the government. The higher $\gamma$, the more independent the central bank and the higher its weight in monetary policy. The

\footnotetext{
instance, compare the maxima of the computed differences under alternative thresholds.

${ }^{27}$ For a motivation for the use of AIC in the present context see the overview in Tong (1993).

${ }^{28}$ This number will change, because different orders of the VAR models imply different effective sample sizes.
} 
parameters $\lambda_{C B}$ and $\lambda_{G o v}$ indicate, respectively, the central bank's and the government's preference for the real target. Following Rogoff (1985), a plausible assumption is that $\lambda_{C B}<\lambda_{\text {Gov }}$. Obviously, then, we would, expect effective monetary policy to be more conservative, the more independent and conservative the central bank (the higher $\gamma$ and the lower $\lambda_{C B}$ ) and the more conservative the government (the lower $\lambda_{G o v}$ ).

If the framework described by (9) and (10) is indeed a valid description of the way monetary policy decisions are made, the evidence presented previously on Bundesbank behaviour could be misleading. Perhaps the less active stabilisation behaviour of nonconservative majorities was due to the dominance of non-conservative governments, and vice versa. In order to investigate this hypothesis, we need to extend our analysis to take into account both Bundesbank and government preferences. The approach used is, again, to split our sample in order to allow us to compare the behaviour of different types of Bundesbank Council majorities under alternative government regimes. While this reduces the number of observations in the resulting sub-samples, it is a rather straightforward procedure that avoids many of the complications involved in introducing interactive dummy variables when estimating VAR model(s). ${ }^{29}$

For the sake of simplicity, we will define conservative and non-conservative Bundesbank regimes based on the median voter hypothesis. Using the "best fit" threshold (see Section 4) does not change our results, though. Conservative (non-conservative) government majorities are defined as periods in which the federal German government was dominated (was not dominated) by the conservative party. ${ }^{30} \mathrm{We}$ focus on the federal government alone because the Bundesbank law is determined (solely) on the federal level (Stern 1998). As already stated in the discussion of the procedure used to identify the central bank's policy preferences, conservative governments are assumed to be more inflation-averse (have a lower $\lambda_{\text {Gov }}$ ) than non-conservative ones. This leaves us with a set of four Bundesbank/government regimes. Based on equations (9) and (10), we would expect the interest rate to be higher and inflation to be lower, the higher the overall degree of conservatism, that is the more conservative the

\footnotetext{
${ }^{29}$ Since we are interested in the dynamic interaction between the variables dependent on the Bundesbank regime, the alternative would be the use of slope dummies. However, in an approach with four regimes such an exercise would quickly exhaust the available degrees of freedom.

${ }^{30}$ This leaves us with a conservative government regime 1950:01-1966:11 and 1982:10-1994:12 and a nonconservative regime 1966:11-1982:09. Excluding the ("neutral") coalition between social democrats and conservatives (1966:12-1969:09) from the latter category does not change the results.
} 
Bundesbank and the government in aggregate. Table 4 reports the mean interest rate and rate of inflation as well as the number of observations for each category. ${ }^{31}$

[Table 4 about here]

From the perspective of the bargaining model, the results are mixed at best. While the changes in the rate of inflation between regimes are more or less in line with the predictions of the model ( 3 out of 4 cases fit), the changes in the nominal interest rates are not. Here only 1 out of 4 cases fit the model. The change from a conservative to a non-conservative Bundesbank regime under a conservative government is the only case in which the nominal interest rate decreases as expected. At the same time, it is also the only occasion on which inflation decreases as the aggregate degree of conservatism decreases. ${ }^{32}$ All in all, it would seem that the bargaining hypothesis is a better predictor of differences in policy outcomes than of differences in policies themselves - hardly a consistent finding. It should also be noted that the qualitative effect of changes in government regime on Bundesbank behaviour are the same under conservative and non-conservative Council regimes. The question is whether this indifference result also holds for stabilisation policy.

To answer this question, we first estimate a separate VAR of the familiar form modelled in equation (1) for each of the four regimes already described in Table 4. All models are corrected for small sample bias (see Section 2). Second, we retrieve a generalised impulse response function describing the Bundesbank's interest rate reaction to a simultaneous compound shock in output growth, money growth, and inflation. The reaction to the compound shock provides a good summary of the reaction to singular shocks in each of the three variables (not reported). Figure 5 displays the generalised impulse functions and Figure 6 the differential reactions across regimes.

[Figure 5 about here]

A first result is that the relative performance between the two types of majority remains unaffected by the ruling government. Conservative Council majorities react more strongly to

\footnotetext{
${ }^{31}$ There are no systematic differences between output growth and money growth under the different regimes.

${ }^{32}$ The net effect on the average real interest rate of a decrease in overall conservatism is negative in 2 out of 4 cases.
} 
expansionary shocks under both conservative (VAR1, VAR2 in Figure 5) and nonconservative governments (VAR3, VAR4), and the difference is significant (lower half of Figure 6).

The analysis of the behaviour of Bundesbank majorities across government regimes yields more mixed results. On the one hand, conservative Councils do not show a significantly different stabilisation pattern under non-conservative and conservative governments (see VAR1 and VAR3 in Figure 5, and the upper left graph in Figure 6). On the other hand, nonconservative majorities clearly react differently under alternative government regimes (VAR2, VAR4). A non-conservative Bundesbank Council raises interest rates in reaction to expansionary shocks almost as much as a conservative Council does, as long as the government is conservative-dominated. But it returns to the more passive behaviour characterising the overall stabilisation performance of non-conservative Council majorities (see Figure 2) once the government is non-conservative. This behavioural difference is significant, as the upper right graph in Figure 6 shows.

[Figure 6 about here]

The finding that only non-conservative Bundesbank Councils soften their reaction to expansionary shocks when the federal government is non-conservative (and vice versa) suggests that we must reject the weighted average or bargaining framework described in equations (9) and (10) above for monetary stabilisation policy. Instead it seems as if "conservatism dominates", i.e., that the Bundesbank follows an active stabilisation policy whenever either the government or the Bundesbank Council is ruled by a conservative majority. One way to solve this puzzle is to allow for a more complicated process by which effective preferences concerning monetary policy are formed. One could, for instance, take into account the fact that the well-known inflation-aversion of the German public works rather passively. German public opinion often rallies behind a proposal for a conservative stabilisation policy, but rarely enforces a conservative policy stance when neither the central bank nor the government is advocating it. ${ }^{33}$

\footnotetext{
${ }^{33}$ See Berger (1997a). The implicit assumption that no third party can trigger support for a conservative stabilisation policy seems to be in line with the fact that, historically, public debates on monetary policy issues in Germany have been started by either the government or the Bundesbank. See, for instance, the account of historical conflicts concerning monetary policy by Neumann (1998). Berger (1997b) reports cases from the early 1950s and 1960s in which the government demanded conservative policy action from the Bundesbank.
} 


\section{Conclusion}

Does conservatism matter for monetary policy? The consensus view that it does matter has grown stronger with every paper written on the cross-country correlation between measure of central bank independence/conservatism and inflation since Bade and Parkin (1984). The stylised fact emerging from this literature is that a more conservative central bank, given sufficient independence from a less conservative government, helps to lower both the level and the variance of inflation (Eijffinger and de Haan 1996). The consensus view is also very much in line with theory, because this is exactly why a society with a preference for low and stable inflation has an incentive to delegate monetary policy to a relatively conservative central banker in the first place (Rogoff 1985). The idea also has proved to be a powerful force in shaping real world institutions. In order to control inflation, the EMU's European System of Central Banks was deliberately modelled on one of the most independent and conservative central banks, the German Bundesbank, and it is, if anything, even more inflation-averse and autonomous than its role model (de Haan 1997). But, according to a growing number of critics, such reforms may have been premature.

The critique of the consensus view argues that the available evidence is incomplete and insufficient. It may be incomplete because of its focus on outcomes instead of policies. It is certainly far from clear whether the observed cross-country differences in inflation and inflation variance are the consequence of differences in monetary policy and thus central bank conservatism, or of other determinants. A more complete test would, for instance, look for higher interest rates and a more active stabilisation policy under more conservative central banks (Svensson 1998). The existing empirical evidence also may be insufficient because it is based on measures of central bank characteristics that unsystematically conflate conservatism and independence. In addition, the traditional literature often uses measures based on legal rather than behavioural data and ignores their possible endogeneity with regard to, for instance, the nature of the financial system (Forder 1996). The criticism is potentially severe, but by no means insurmountable. One way to address it is to use a different approach than the conventional cross-country one.

In this paper we argue that a single-country framework is much better equipped to deal with many of the arguments raised against the evidence stemming from the traditional crosscountry literature. Quite obviously, a single-country approach avoids the necessity of producing reliable measures of central bank characteristics across different countries. An even 
more important advantage is that it allows a more detailed analysis, especially of the dynamic properties of central bank behaviour. In addition, it makes it much easier to distinguish between central bank independence and conservatism. Focusing on the example of the German Bundesbank, which is characterised by a virtually time-invariant degree of independence in the post-war period, we are able to identify conservative and non-conservative regimes in the bank's policy Council by looking at the political background of individual members. This identifying assumption is supported by an analysis of individual voting behaviour, which shows that conservative nominees are less likely to resist interest rate increases than non-conservative nominees. Yet another advantage of the single-country approach is that possible determinants which influence both policy outcomes of central bank behaviour, such as the strength of the financial sector, have been shown to be time-invariant in the German case (Posen 1995).

Does conservatism matter for monetary policy, once we change from a cross-country to a single-country perspective? Our main findings suggest it does. First, we find that, based on a sample of monthly data running from January 1951 to December 1994, conservative Bundesbank Council majorities are associated with somewhat higher short-term interest rates, marginally lower rates of inflation, and a lower inflation variance than non-conservative majorities. This is in line with a majority of panel studies on central bank independence/conservatism and inflation. We also find output and money volatility to be lower under conservative central bank regimes. This corresponds to our second finding, namely the fact that the Bundesbank reacts more decisively to expansionary shocks to output growth, money growth, and inflation when the Council is conservative than when it is nonconservative. It is also interesting to note, thirdly, that the Bundesbank increases its stabilisation efforts as the percentage of conservative votes in its Council becomes larger. In fact, the vote margin that produces the "best fit" for conservative and non-conservative Bundesbank regimes is below the 50 percent mark suggested by the median voter theorem. In summary, it would seem that the findings arising from a single-country approach do not reject the hypothesis that central bank conservatism matters for monetary policy.

The basic outcomes summarised above are quite robust. The policy differences between conservative and non-conservative Bundesbank regimes do not, for instance, depend on the inclusion or exclusion of the Bretton Woods period or on government pressure. Interestingly enough, only non-conservative Council majorities strengthen their stabilisation efforts if the reigning government is conservative. While this particular result is hardly in line with the view of monetary policy as a straightforward bargaining process between central banks and 
governments advocated by Eijffinger and Hoebrichts (1998) and Franzese (1999), it is consistent with the fact that monetary policy (even in Germany) is not conducted in political vacuum. It might also provide a lead for future research concerning the effects of central bank conservatism on policy and policy outcomes. Future research might also aim at extending the analysis to other countries than Germany. For instance, it would be interesting to investigate whether the changes in the U.S. Fed's policy activism identified by Christiano et al. (1998) are related to changing degrees of conservatism in the Open Market Committee.

An interesting implication of our findings is that political background matters. The assumption that Bundesbank Council members nominated by left-wing-dominated governments are less inflation-averse than those appointed by right-wing governments proved to be valid in tests both of individual- and majority-based decision making. What does this imply for the Bundesbank's successor, the European System of Central Banks? Following the same principles as govern the Bundesbank, the current ESCB Board is characterised by a balance between "hawks" and "doves". Of its 17 members, 6 are conservative nominees, 6 are non-conservative, and 5 fall into the "neutral" category, having been appointed by middle-ofthe-road governments. This balance of power is destined to change, however, as the new leftwing-dominated governments of the European Monetary Union have the opportunity of appointing their own candidates, in place of those nominated by their right-wing predecessors. For instance, the new German government is expected to replace the outgoing Bundesbank Governor, Hans Tietmeyer, a former member of the conservative federal government, with Ernst Welteke, currently Governor of the local central bank of Hesse, former Minister of Finance in Hesse's left-wing government, and social-democratic party member. ${ }^{34}$ If the behaviour of the Bundesbank Council provides a basis for predicting that of the ESCB, we should certainly expect a somewhat less conservative policy stance in the future.

\footnotetext{
34 The Financial Times (May 12 1999: p.1) reported that Welteke "is considered unlikely to join forces with...the "hardliners"" camp in the ECB's governing council."
} 


\section{References}

Alesina, Alberto (1987), "Macroeconomic Policy in a Two-Party System as a Repeated Game", Quarterly Journal of Economics, 102, 651-678.

Bade, Robin and Michael Parkin (1984), "Central Bank Laws and Monetary Policy", Mimeo. Ball, Laurence (1997), "Efficient Rules for Monetary Policy", NBER Working Paper, 5952.

Berger, Helge (1997a). "The Bundesbank's Path to Independence. Evidence from the 1950's", Public Choice, 93, 427-453.

Berger, Helge (1997b), Konjunkturpolitik im Wirtschaftswunder, Mohr Siebeck: Tübingen.

Berger, Helge and Ulrich Woitek (1997a), "Searching for Political Business Cycles in Germany," Public Choice, 91, 179-97.

Berger, Helge and Ulrich Woitek (1997b), "How Opportunistic Are Partisan German Central Bankers: Evidence on the Vaubel Hypothesis", European Journal of Political Economy, 13(4), 807-822.

Berger, Helge and Ulrich Woitek (1999), "Further Observations on the Political Business Cycle in German Monetary Aggregates", University of Glasgow, Working Papers in Economics, No 9902.

Bernanke, Ben S., Thomas Laubach, Frederic S. Mishkin, and Adam A. Posen (1999), Inflation Targeting, Lessons from the International Experience, Princeton: Princeton Univserity Press.

Bernanke, Ben S. and Ilian Mihov (1997), "What Does the Bundesbank Target?", European Economic Review, 41(6), 1025-1053.

Blanchard, O.J. and D. Quah (1989), "The Dynamic Effects of Aggregate Demand and Supply Disturbances," American Economic Review, 34, 355-363.

Blinder, Alan S. (1998), Central Banking in Theory and Praxis, Cambridge, MA: MIT Press.

Cecchetti, Stephen G., Margaret M. McConnell, and Gabriel Perez Quiros (1999), "Policymakers' Revealed Preferences and the Output-Inflation Variability Trade-Off: Implications for the European System of Central Banks", Mimeo (preliminary draft).

Christiano, Lawrence J, Martin Eichenbaum, and Charles L. Evans (1998), "Monetary Policy Shocks: What Have We Learned and To What End?", NBER Working Paper, 6400.

Chappel, Henry W. Jr., Rob Roy McGregor and Todd Vermilyea (1999), "Models of Monetary Policy Decision-Making: Arthur Burns and the Federal Open Market Committee", Mimeo.

Clarida, Richard and Mark Gertler (1997), "How the Bundesbank Conducts Monetary Policy", in: C. Romer and D. Romer (eds.), Reducing Inflation, Chicago: University of Chicago Press.

Cukierman, Alex (1992), Central Bank Strategy, Credibility and Independence: Theory and Evidence, Cambridge (Mass.), MIT Press.

Cukierman, Alex (1996), "The Economics of Central Banking", in: Wolf, Holger C. (e.d), Macroeconomic Policy and Financial Systems, forthcoming.

De Haan, Jakob de (1995), "Comment", in: Huizinga, Harry P. (ed.), Positive Political Economy: Theory and Evidence, forthcoming.

De Haan, Jakob (1997), "The European Central Bank: Independence, Accountability and Strategy: A Review", Public Choice, 93, 395-426.

De Haan, Jakob and Willem Kooi (1997), "What Really Matters: Conservativeness or Independence?", Banca Nazionale de Lavoro Quarterly Review, 200, 23-38.

Efron, Bradley and Robert J. Tibshirani (1993), An Introduction to the Bootstrap, New York: Chapman \& Hall.

Eijffinger, Silvester C.W. and de Haan, Jakob (1996), The Political Economy of CentralBanking, Princeton Special Papers in International Economics, No. 19. 
Eijffinger, Silvester C.W. and Marco Hoebrichts (1998), "The Trade Off Between Central Bank Independence and Conservativeness", Oxford Economic Papers, 50, 397-411.

Eijffinger, Silvester C.W., Maarten van Rooj, and Eric Schaling (1996), "Central Bank Independence: A Paneldata Approach", Public Choice, 89, 163-189.

Favero, Carlo A. and Riccardo Rovelli (1999), "Modeling and Identifying Central Banks' Preferences", Mimeo (preliminary draft).

Financial Times (May 12 1999), “'Mr Spontaneity' to Take Bundesbank Into New Era”, 1.

Forder, James (1996), "On the Assessment and Implementation of 'Institutional Remedies", Oxford Economic Papers, 48, 39-51.

Franzese, Robert J. (1999), "Partially Independent Central Banks, Politically Responsive Governments, and Inflation", Mimeo (forthcoming in: American Journal of Political Science).

Havrilesky, Thomas and John Gildea (1991), "Screening FOMC Members for their Biases and Dependability", Economics and Politics, 3(2), 139-49.

Hibbs, Douglas (1977), "Political Parties and Macroeconomic Policy", American Political Science Review, 71, 1467-1468.

Kenen, Peter B. (1995), Economic and Monetary Union in Europe, Moving Beyond Maastricht, Cambridge: Cambridge University Press.

Kilian, Lutz (1998), "Small-Sample Confidence Intervals for Impulse Response Functions," Review of Economics and Statistics, LXXX, 218-230.

Koop, G. M. H. Pesaran, and S.M. Potter (1996), "Impulse Response Analysis in Nonlinear Multivariate Models," Journal of Econometrics, 74, 118-147.

Kydland, Finn E. and Edward C. Prescott (1977), "Rules Rather than Discretion: The Inconsistency of Optimal Plans", Journal of Political Economy, 85, 473-491

Maier, Philipp and De Haan, Jakob (1998), "How Independent Is the Bundesbank Really? A Survey", in: Jakob de Haan (ed.), 50 Years of Bundesbank: Lessons for the ECB, London: Routledge (forthcoming).

Neumann, Manfred J. M. (1991), "Precommitment by Central Bank Independence," Open Economies Review, 2, 95-112.

Neumann, Manfred J.M. (1998), "Geldwertstabilität: Bedrohung und Bewährung", in: Deutsche Bundesbank, Fünfzig Jahre Deutsche Mark, Notenbank und Währung in Deutschland seit 1948, München: Beck, 309-346.

Obstfeld, Maurice (1993), The Adjustment Mechanism", in: Michael D. Bordo and Barry Eichengreen (eds.), A Retrospective on the Bretton Woods System: Lessons for International Monetary Reform, Chicago: University of Chicago Press, 201-68.

Peersman, Gert and Frank Smets (1998), "Uncertainty and the Taylor Rule in a Simple Model of the Euro-Area", Mimeo.

Pesaran, H. M. and Y. Shin (1998), "Generalised Impulse Response Analysis in Linear Multivariate Models," Economics Letters, 58, 17-29.

Posen, Adam S. (1993), "Why Central Bank Independence Does Not Cause Low Inflation: There Is No Institutional Fix for Politics", in: O'Brien, Richard (ed.), Finance and the International Economy (7), Oxford, Oxford University Press, 53-84.

Posen, Adam S. (1995), "Declarations Are Not Enough: Financial Sector Sources of Central Bank Independence", in: Ben S. Bernanke and Julio J. Rotemberg (eds.), NBER Macroeconomics Annual 1995, Cambridge/MA, MIT Press, 253-274.

Rogoff, Kenneth (1985), "The Optimal Degree of Commitment to an Intermediate Monetary Target”, Quarterly Journal of Economics, 100, 1169-1189.

Romer, D. (1993), "Openess and Inflation: Theory and Evidence", Quarterly Journal of Economics, 108, 869-903. 
Rudebusch, Glenn D. and Lars Svensson (1998), "Policy Rules for Inflation Targeting", Mimeo.

Sieg, Gernot (1997), "A Model of Partisan Central Banks and Opportunistic Political Business Cycles", European Journal of Political Economy, 13(3), 503-516.

Sims, C. (1980), "Macroeconomics and Reality," Econometrica, 48, 1-49.

Stern, Klaus (1998), "Die Notenbank im Staatsgefüge", in: Deutsche Bundesbank, Fünfzig Jahre Deutsche Mark, Notenbank und Währung in Deutschland seit 1948, München: Beck, 141-98.

Svensson, Lars (1998), "Inflation Targeting as a Monetary Policy Rule", NBER Working Paper, 6790 (forthcoming Journal of Monetary Economics).

Tong, Howell (1993), Non-Linear Time Series. A Dynamical Systems Approach. Oxford University Press.

Vaubel, Roland (1997a), "The Bureaucratic and Partisan Behaviour of Independent Central Banks: German and International Evidence", European Journal of Political Economy, 13(2), 201-224.

Vaubel, Roland (1997b), "Reply to Berger and Woitek", European Journal of Political Economy, 13(4), 823-827.

Walsh, Carl. E. (1995), "Optimal Contract for Central Bankers", American Economic Review, $85(1), 150-167$. 

Table 1: Evidence from Individual Dissent Voting Behaviour (1948-61)

\begin{tabular}{|c|c|c|c|c|c|c|c|}
\hline & \multicolumn{2}{|c|}{$\begin{array}{c}\text { Conservative } \\
\text { Nominees }\end{array}$} & \multicolumn{2}{|c|}{$\begin{array}{l}\text { Social Democratic } \\
\text { Nominees }\end{array}$} & \multicolumn{3}{|c|}{ Neutral Nominees } \\
\hline & (1) & (2) & (3) & (4) & $(5)$ & $(6)$ & (7) \\
\hline Constant & $\begin{array}{l}14.22 * * * \\
(3.73)\end{array}$ & $\begin{array}{c}5.63 \\
(1.39)\end{array}$ & $\begin{array}{l}19.26^{* * * *} \\
(4.62)\end{array}$ & $\begin{array}{l}11.82 * * \\
(2.70)\end{array}$ & $\begin{array}{l}9.23 * * \\
(2.19)\end{array}$ & $\begin{array}{c}2.61 \\
(0.65)\end{array}$ & $\begin{array}{c}1.31 \\
(0.27)\end{array}$ \\
\hline $\begin{array}{c}\Delta \text { Discount } \\
\text { Rate }\end{array}$ & $\begin{array}{c}0.92 \\
(0.19)\end{array}$ & $\begin{array}{l}-2.45 \\
(0.52)\end{array}$ & $\begin{array}{c}7.57 * \\
(1.97)\end{array}$ & $\begin{array}{c}7.08 * \\
(1.87)\end{array}$ & $\begin{array}{l}11.76 \\
(1.40)\end{array}$ & $\begin{array}{c}9.15 \\
(1.05)\end{array}$ & $\begin{array}{l}11.24 * * \\
(2.61)\end{array}$ \\
\hline $\begin{array}{l}\text { Social Dem. } \\
\text { "No" Votes }\end{array}$ & & $\begin{array}{l}0.44 * * * \\
(3.24)\end{array}$ & & & & $\begin{array}{l}0.34 * * \\
(2.55)\end{array}$ & \\
\hline $\begin{array}{l}\text { Conservative } \\
\text { "No" Votes }\end{array}$ & & & & $\begin{array}{l}0.52 * \\
(2.09)\end{array}$ & & & $\begin{array}{l}0.55^{* *} \\
(2.49)\end{array}$ \\
\hline$R^{2}$ (adj.) & -0.05 & 0.13 & 0.06 & 0.23 & 0.20 & 0.26 & 0.39 \\
\hline Obs. & 19 & 19 & 19 & 19 & 19 & 19 & 19 \\
\hline
\end{tabular}

Notes: $* * * / *$ indicate significance at the 1 and 10 percent level respectively. White $\mathrm{HC}$ t-Statistics in parentheses below coefficients. The LHS variables are the percentage of conservative (columns (1) and (2)) and social democratic Council nominees (columns (3) and (4)) that voted "no" on the proposed discount rate change. The term "Neutral" refers to nominees appointed to the Council by governments that were dominated by neither of the two parties (columns (5), (6) and (7)). $\Delta$ Discount Rate is the change in the Bundesbank discount rate, the bank's main policy instrument at the time, in percentage points. 
Table 2: Output, Money, and Inflation, by Bundesbank Majority

\begin{tabular}{ccccc}
\hline \hline & \multicolumn{2}{c}{ Conservatives } & \multicolumn{2}{c}{ Non-Conservatives } \\
& mean & standard deviation & mean & standard deviation \\
$i$ & 5.47 & 2.49 & 5.41 & 2.48 \\
$y$ & 4.20 & 6.41 & 3.57 & 6.97 \\
$m$ & 8.18 & 3.13 & 7.88 & 4.02 \\
$\pi$ & 2.99 & 1.70 & 3.01 & 2.28 \\
\hline
\end{tabular}

Notes: Monthly data as described in the text and footnotes. Sample is 1951:011994:12 after computing growth rates. As mentioned, $m$ has been corrected for the one-off effects of German unification. The qualitative results are fairly similar if we abbreviate the sample to exclude the Bretton Woods period (see footnotes) and/or the immediate post-war and post-unification years. 
Table 3: Shocks under conservative/non-conservative majorities

\begin{tabular}{lcccc}
\hline \hline & & $\mathrm{u}_{\mathrm{y}}$ & $\mathrm{u}_{\mathrm{m}}$ & $\mathrm{u}_{\pi}$ \\
\hline Coefficient of correlation & $\mathrm{u}_{\mathrm{y}}$ & - & - & - \\
& $\mathrm{u}_{\mathrm{m}}$ & $-0.05 /-0.13$ & - & - \\
& $\mathrm{u}_{\pi}$ & $-0.15 /-0.04$ & $0.09 / 0.02$ & - \\
\hline Standard deviation & & $2.6 / 2.4$ & $0.8 / 0.7$ & $0.3 / 0.3$
\end{tabular}

Note: The table presents statistics on the shocks in the VAR model described in equation (8). The first figure refers to conservative, the second to non-conservative majorities in the Bundesbank Council. $\mathrm{u}_{\mathrm{y}}, \mathrm{u}_{\mathrm{m}}$, and $\mathrm{u}_{\pi}$ are the residuals from the output growth, money growth, and inflation equations from the estimated model under the median voter assumption. 
Table 4: Bundesbank and Government Majorities

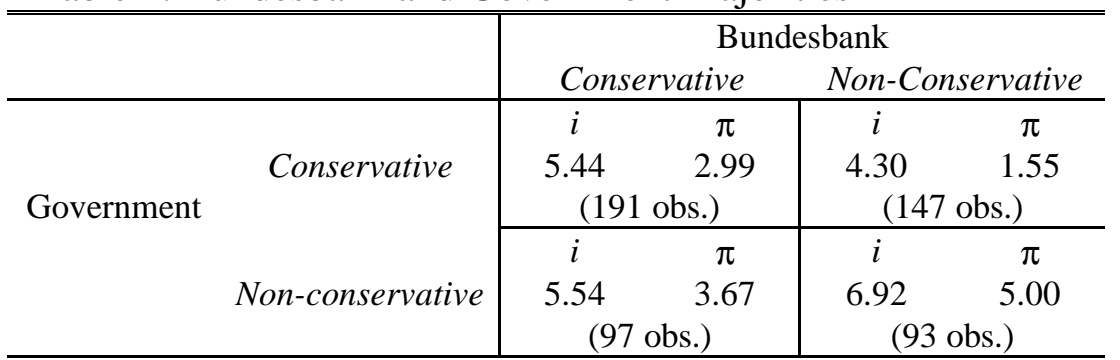

Note: Data as in Table 2. Table shows the mean (nominal) interest rate and mean inflation rate under the respective Bundesbank/government regime. See text for details. 
Figure 1: The Time Path of Bundesbank Council Votes
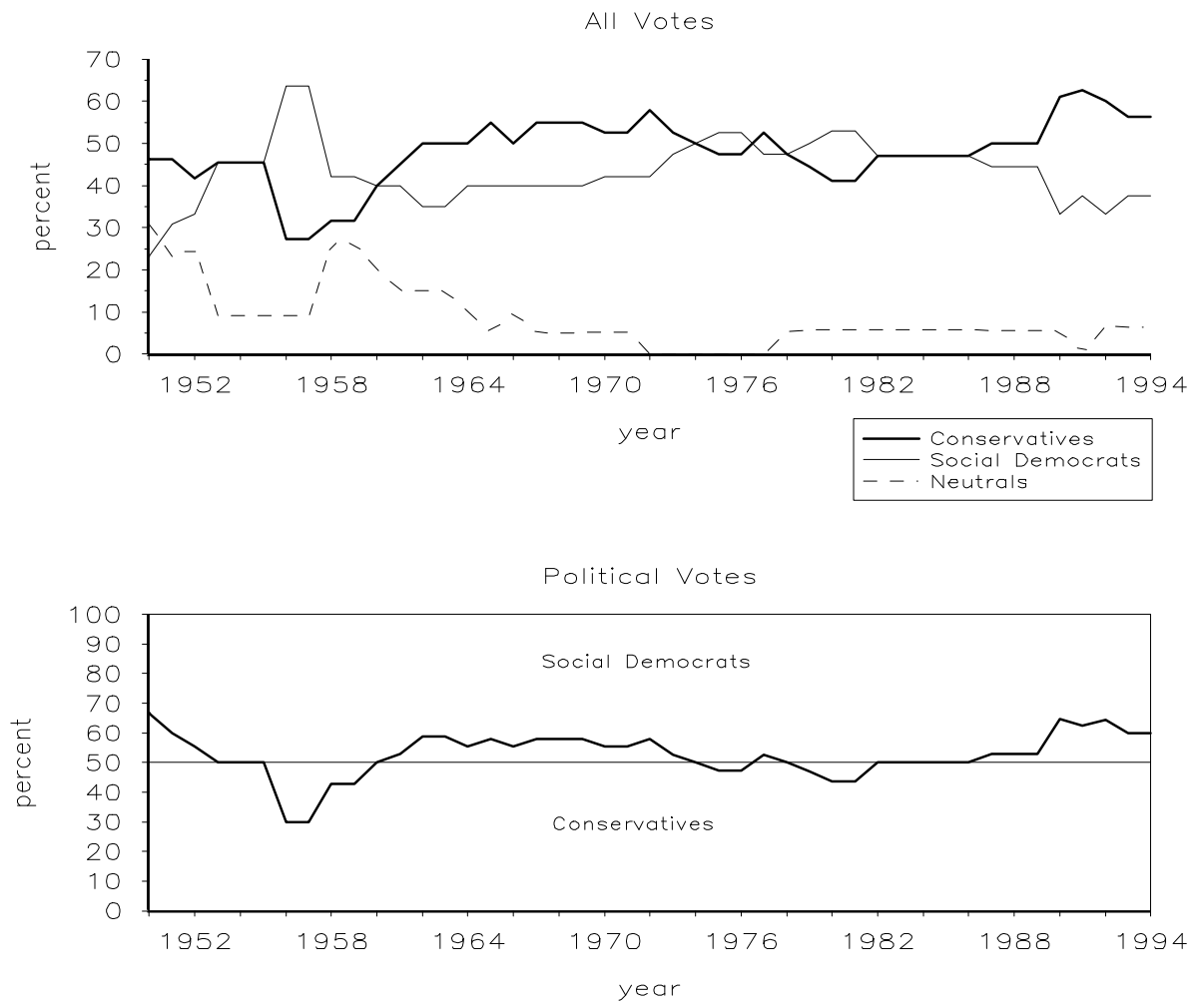

Note: Political vote shares are defined as the share of either conservative or social democratic nominees in the Council, excluding nominees of neutral governments. Source: Vaubel (1997a), own calculations. 
Figure 2: Conservative and Non-conservative Impulse Responses (1)

Conservative
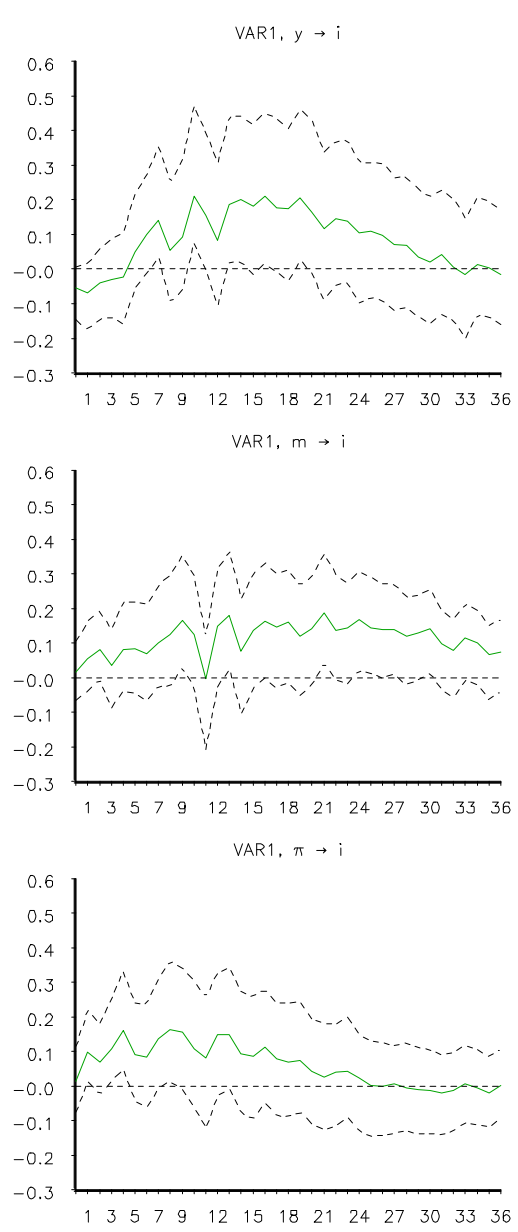

Non-conservative
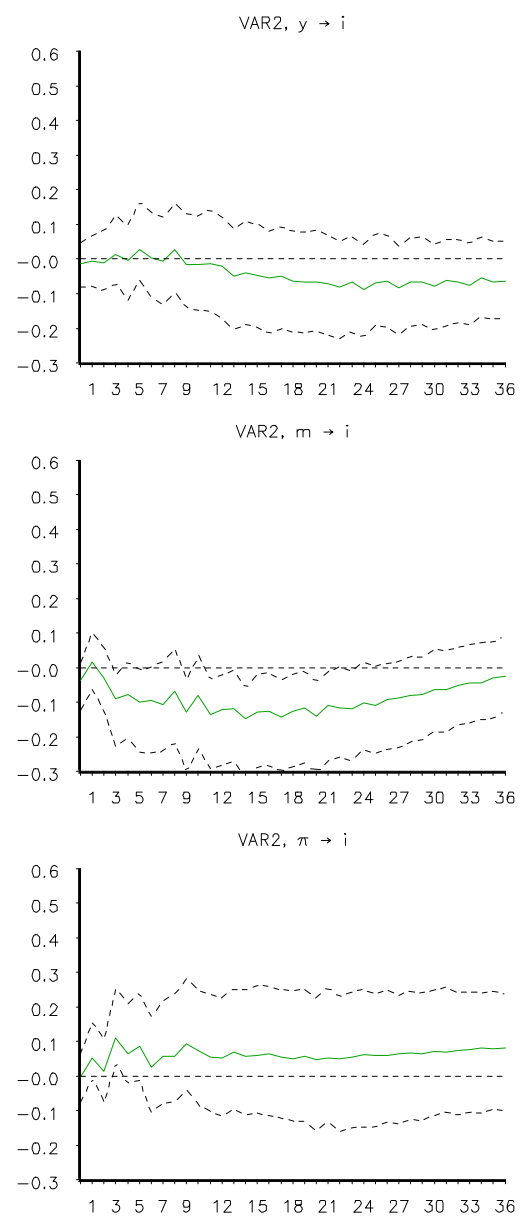

Difference
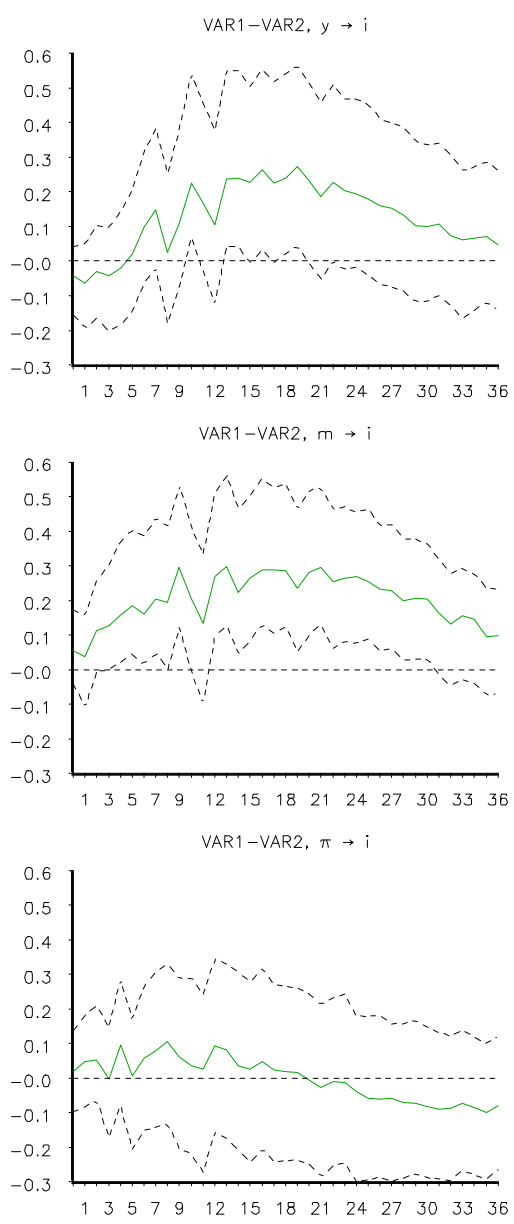

Note: VAR1 marks the impulse responses of the interest rate to shocks in $y, m$, and $\pi$ under conservative Bundesbank Council majorities, VAR2 the responses under non-conservative majorities. The third column displays the computed difference between the policy reaction under the two regimes. A conservative regime is defined as one in which the Council's median voter has been nominated by a conservative government. 
Figure 3: Conservative and Non-conservative Impulse Responses (2)

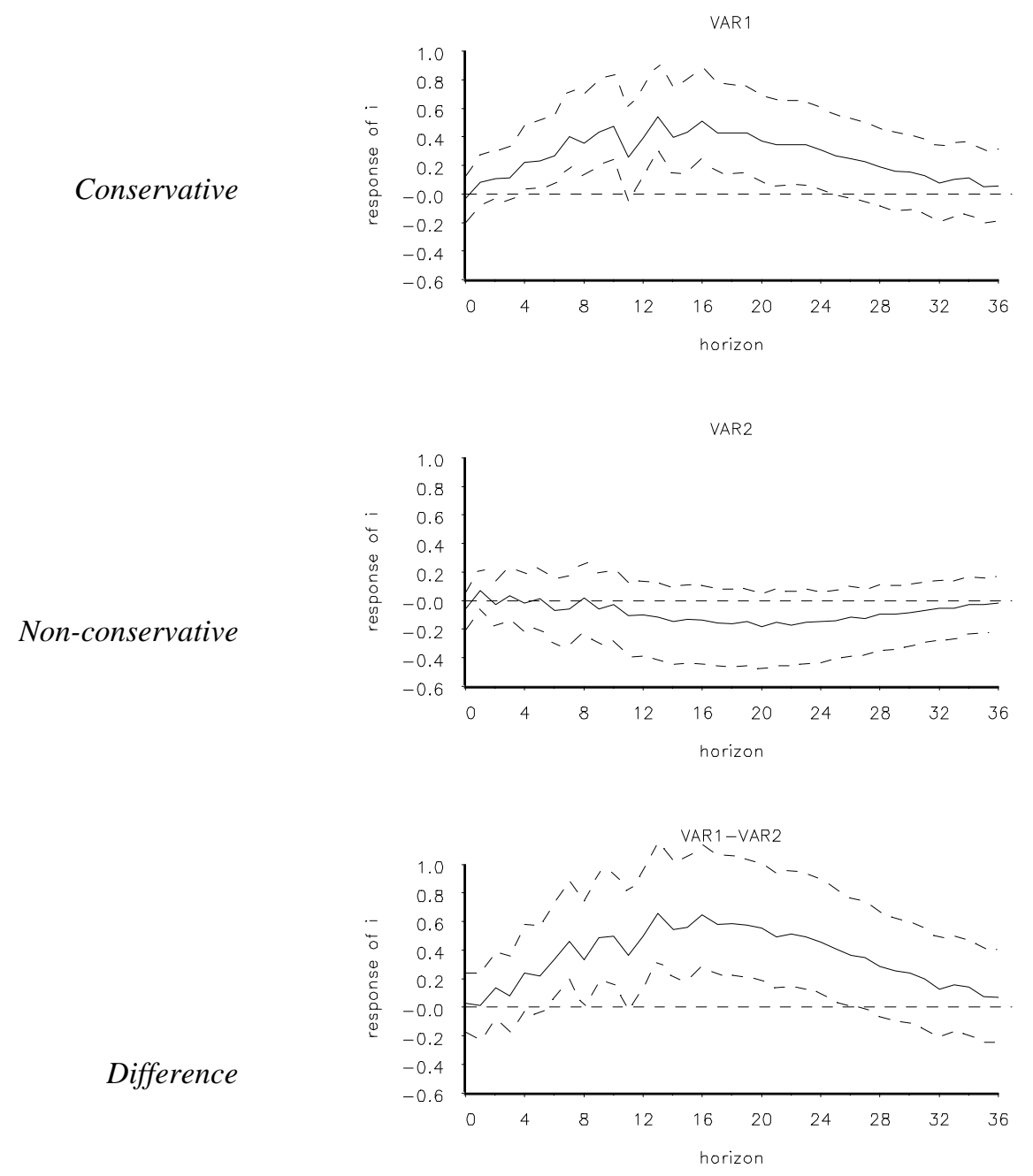

Note: Tables show the impulse response of the interest rate to a compound simultaneous shock in $y, m$, and $\pi$ under different Council majorities. See the note to Figure 2. See Section 2 on the concept of a compound shock. 
Figure 4: Conservative Vote Share and Stabilisation Effort

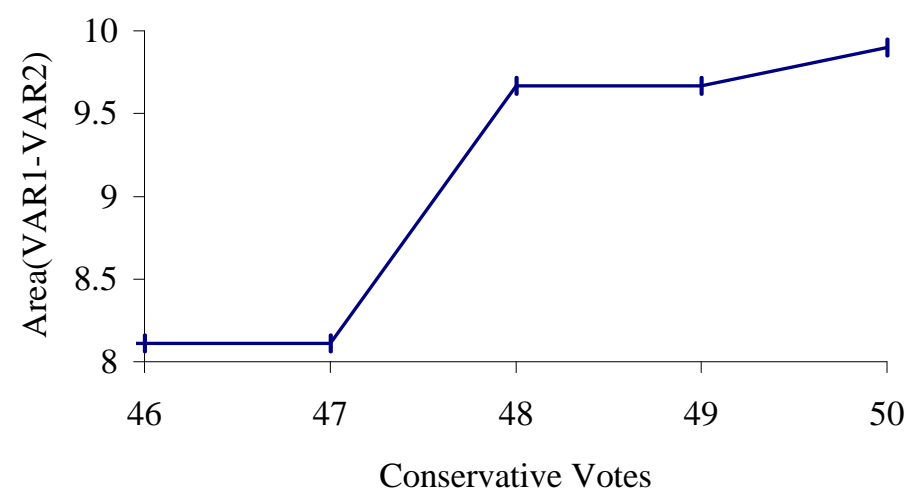

Note: The figure shows the difference between the areas under the impulse response functions for compound macroeconomic shocks under conservative (VAR1) and non-conservative (VAR2) regimes under different thresholds for a conservative majority. 
Figure 5: Bundesbank and Government Majorities

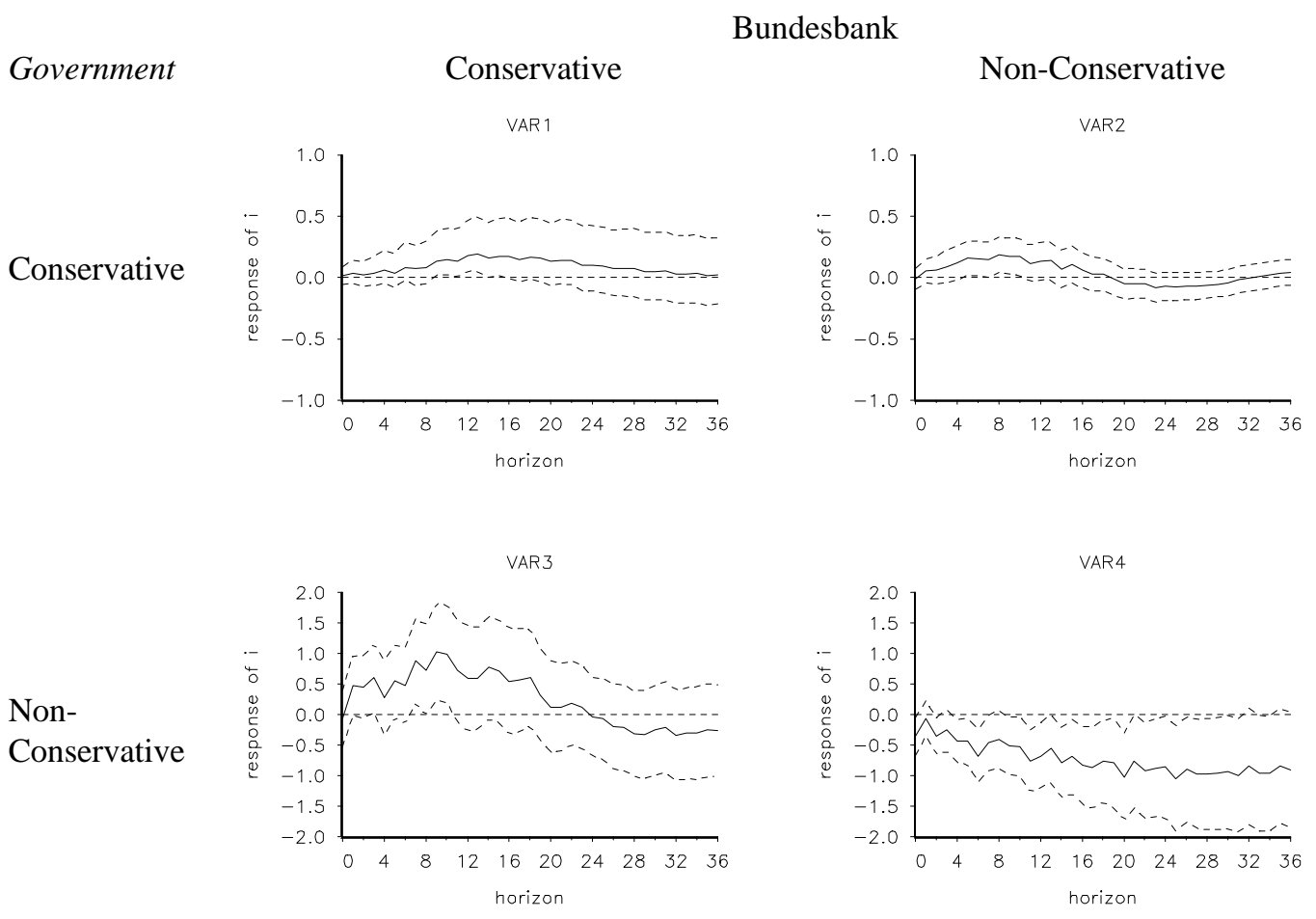

Note: The figure displays the impulse responses of the interest rate to a compound shock in $y, m$, and $\pi$ under different government (rows) and Bundesbank Council majorities (columns). A conservative regime is defined as one in which the Council's (or the government's) median voter has been nominated by a conservative government (is conservative). 
Figure 6: Bundesbank and Government Majority Differences
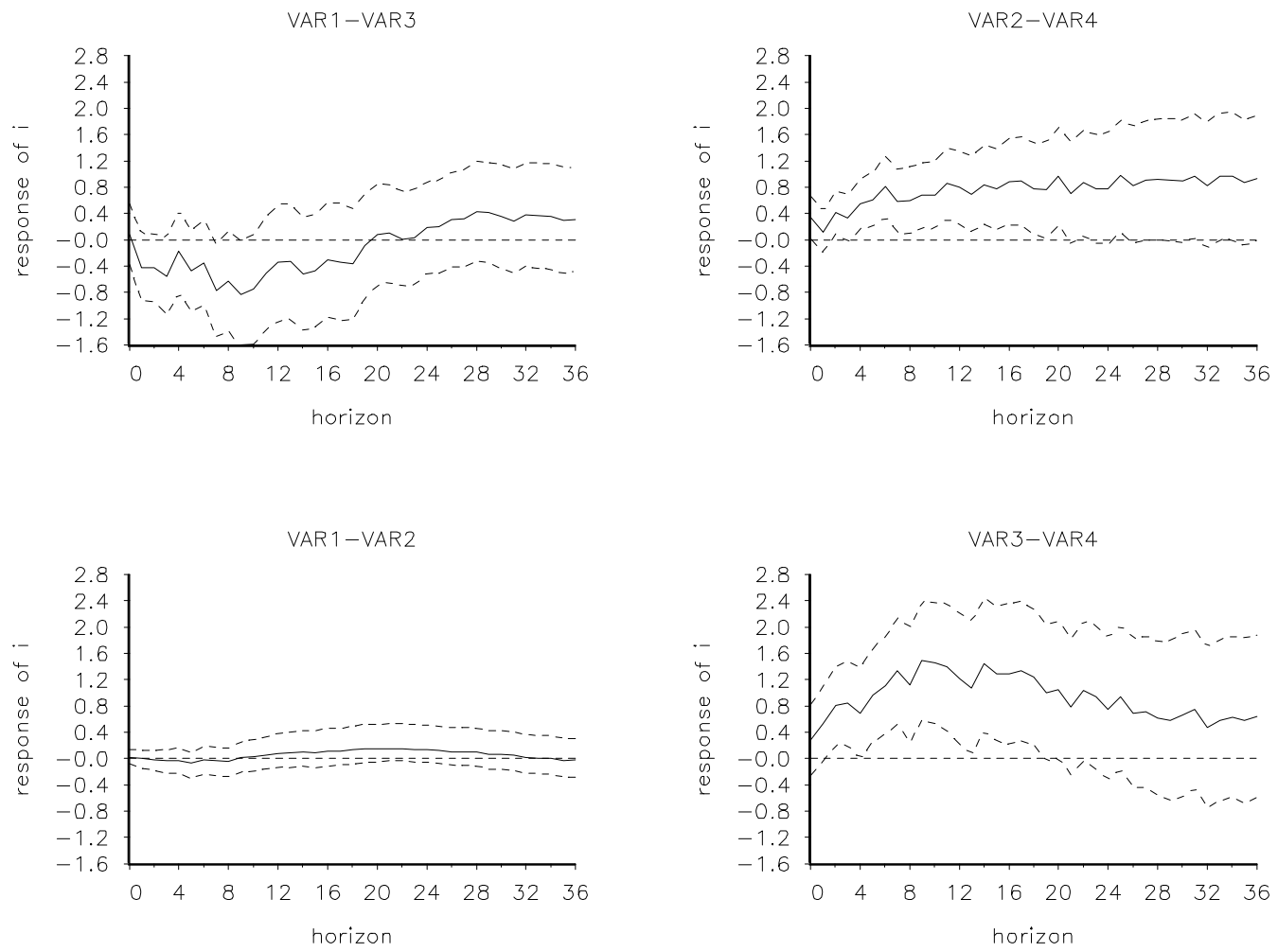

Note: See Figure 5 for definition of the regimes. The first row of graphs shows the behavioural differences for conservative (VAR1-VAR3) and non-conservative (VAR2-VAR4) Council majorities with respect to the government majority. The differences between conservative and non-conservative Council majorities in the case of a conservative government majority (VAR1-VAR2) and a non-conservative government majority (VAR3VAR4) are displayed in the second row of graphs. 